Student Satisfaction and Perceptions of Quality: Testing the Linkages for PhD Students

Ming Cheng, John Taylor, James Williams, \& Kang Tong

University of Wolverhampton, $U K$

University of Liverpool, $U K$

Birmingham City University, UK

East China Normal University, China

Telephone: 0044(0)1413304908

Email address: Ming.Cheng@wlv.ac.uk

Correspondence address: Institute of Education, University of Wolverhampton, WN Building, Walsall Campus, Walsall, WS1 3BD, UK 


\title{
Student Satisfaction and Perceptions of Quality: Testing the Linkages for PhD Students
}

\begin{abstract}
Student satisfaction and the quality of education are of compelling interest to students, academic staff, policymakers and higher education researchers internationally. There is a widespread belief in their "cause and effect" relationship. This paper tests these beliefs and explores how the level of student satisfaction is linked with the perceived quality of $\mathrm{PhD}$ education. Using expectancy-value theory as a framework and interview data from $\mathrm{PhD}$ students and their supervisors, this paper suggests that satisfaction is not necessarily perceived as an indicator of quality education. Levels of student satisfaction can be influenced by students' expectations prior to their study and their pre-conceived beliefs regarding the value of a $\mathrm{PhD}$ education. Concern is raised that an over-emphasis on student satisfaction may pose a threat to the quality of $\mathrm{PhD}$ programmes, making it increasingly difficult for universities to retain their integrity and reducing the intellectual challenges that $\mathrm{PhD}$ students need to experience.
\end{abstract}

Key words: student satisfaction, quality education, expectations, value, $\mathrm{PhD}$ study 


\section{Introduction}

Interest in student satisfaction at undergraduate and graduate level is well-established within higher education in many countries (Nair, Murdocj \& Mertova, 2011). In the US, data on student satisfaction has been collected systematically for many years, associated with aspirations of quality enhancement and sometimes with ideas of student empowerment (Singh, 2002). In England, such ideas led to the establishment of the National Student Survey (NSS) from 2005, which measures undergraduate students' satisfaction with their learning experience (Higher Education Funding Council for England [HEFCE], 2011). Similarly, a national survey of student engagement (AUSSE) has been introduced for use across Australian and New Zealand universities to collect information in order to increase understanding of student engagement in university education (Coate, 2014). These developments have been stimulated by increasing demands for public accountability, but have also been rooted in research showing positive connections between student satisfaction and motivation, retention and long-term philanthropy (Sum, McCaskey \& Kyeyune, 2010).

However, the use of student satisfaction as a mechanism for driving up quality has been contested. For example, Shah (2012) argued that the monitoring of student experience through engaging representative samples of students has had limited impact on improving levels of student satisfaction. Williams (2013, p.99) holds a similar view and argues that surveys of student satisfaction mainly measure 'how students subjectively feel at a particular point in time, their success in the programme to date (in terms of grades) and the extent to which any demands they have made on lecturers have been met'. It is worth noting that these studies focus on undergraduate experience, and that doctoral students' learning experience can be quite different from that.

Notwithstanding these concerns, the use of student satisfaction surveys at postgraduate level is growing, including surveys for research students. Traditionally, surveys among $\mathrm{PhD}$ students have tended to focus on identifying particular issues, such as supervision, research training and employability, and have been undertaken largely for internal institutional use and for quality enhancement. Today, more broadly based surveys aimed at measuring and comparing experiences and satisfaction of doctoral students within and across institutions are emerging. For example, in the UK, the first Postgraduate Research Experience Survey (PRES) was undertaken in 2007, highlighting broad trends within the organisation and delivery of 
postgraduate research (Higher Education Academy [HEA], 2014). This survey is now increasingly used by university managers to evaluate the experiences of doctoral students and by prospective students in selecting their place of study. However, little attempt has been made to understand the validity of using student satisfaction surveys at doctoral level as a proxy for the quality of their educational experience.

In order to understand the relationship between student satisfaction and the quality of education experienced by research students, this paper explores whether satisfaction merely reflects a snapshot of student experience or whether there is a perceived cause and effect relationship between student satisfaction and quality education. It interprets the results of an empirical study which sought to understand the perceptions of $\mathrm{PhD}$ students and their supervisors concerning student satisfaction and quality of their $\mathrm{PhD}$ education in the UK. $\mathrm{PhD}$ students are chosen they are under-researched group and it is important to understand the relationship between student satisfaction and the quality of education from their perspectives. This study also considers $\mathrm{PhD}$ research within a changing context, characterised by strong political calls for the measurement of quality and student satisfaction; an increasing focus on graduate employability; reduced public funding and increased student tuition fees; global competition among universities; and the increasing freedom of students to choose their education (Molesworth, Nixon \& Scullion, 2009). Understanding the relevance of student satisfaction to the quality of $\mathrm{PhD}$ study is thus important, as universities compete to attract the best students for research programmes.

\section{Satisfaction: some theoretical approaches}

This paper offers a fresh approach by using expectancy-value theory (Eccles \& Wigfield, 2002) as a framework to consider the nature of student satisfaction and the factors that influence student satisfaction. The theory was originally developed by psychologist Martin Fishbein to explain and predict an individual's attitudes towards objects and actions. Jacquelynne Eccles and her colleagues further developed this theory and argued that expectancies and values could directly influence individuals' choices, persistence and performance (Eccles et al., 1983; Eccles, 1987; Eccles \& Wigfield, 2002). "Expectancy” here refers to an individual's expectations and beliefs about how their performance will lead to either success or failure. "Values" means the task-specific purposes for engaging in a task, with four key components: attainment, cost, and intrinsic and utility values (Eccles, 1987). 
Attainment value is the personal importance of doing well on the task; cost is the effort of engaging in the task; intrinsic value is the enjoyment from performing the activity and interest in the subject; and utility value refers to how well a task relates to current or future goals, for example, career goals.

According to Palacio, Meneses \& Perez (2002), satisfaction results when perceived performance meets or exceeds an individual's expectations. From this perspective, satisfaction is a fulfillment response and the level of student satisfaction will depend on prior estimation of the likelihood of success in performing a certain learning task, how they perceive their learning will result in certain outcomes and the value they place on learning. This paper therefore uses expectancy-value theory to explore whether student satisfaction can be influenced by what students expect before undertaking their $\mathrm{PhD}$ study and by the values they attach to $\mathrm{PhD}$ education, including the personal importance of doing well in the study, interest in their subject area, career plans and the cost of engaging in the study. Comments will also be offered on how the achievement of student satisfaction influences perceptions of quality.

\section{Mainstream notions of quality}

Research concerning quality in education is based on two mainstream approaches: humanistic and mechanistic. The humanistic approach focuses on the views of students and their transformative learning experience; quality is defined as transformation (Harvey, 2006). In contrast, the mechanistic approach emphasizes the evaluation of teaching and learning, mainly conducted by experts and agencies. For example, the UK Quality Assurance Agency (QAA) uses quality enhancement to evaluate the quality of university teaching and learning (Cheng, 2011).

There have been few applications of quality as student transformation and human potential in the higher education sector, because quality has often been used as a management concept to differentiate universities and to attract students in the face of increased international competition. From this perspective, quality is equated with success in globally competitive league tables, and has been interpreted as fitness for purpose and as value for money (Harvey, 2006). This has encouraged a view that higher education is a service product, and the measurement of quality has been linked with students' judgement about their overall educational experience and service outcomes (Gruber et al., 2010). However, this leads to the 
possibility that a high performing university can only be one with satisfied students, unrelated to academic standards (Nixon \& Scullion, 2010).

\section{Linking quality education with student satisfaction}

The relationship between quality education and student satisfaction is much debated. One view is that, if the provision of high quality education is a "service", then it is closely related to levels of student satisfaction (Marzo-Navarro, Pedraja-Iglesias \& Rivera-Torres, 2005), and that quality also results from a comparison of expectations with perceptions of performance (Rowley, 1996; Kahu, 2013). This means that students' perceptions of quality may result from comparing expectations formed prior to receiving the education with their actual experiences (Ismail, Abdullah \& Francis, 2009). However, if the quality of higher education is defined by perceptions, measuring student perceptions is normally based on a snapshot of their education; very few researchers attempt to assess how the perceptions of individual students change over time (Williams, 2013). One exception was Oldfield and Baron (2000) who showed that over time students might become more critical of the quality of provision they received, but this is focused on undergraduate education.

Another argument is that quality education and student satisfaction vary between institutions and cannot be measured objectively. Both depend on core services, such as teaching, research and learning, and academic services (Vauterin, Linnanen \& Marttila, 2011). Perceptions of the quality of these services are difficult to establish and are often highly subjective. Thus, the quality of education may be perceived as the product of an individual student evaluating a number of services provided by lecturers, administrators, their department or school, and the wider university (Bruggen, Fouber \& Gremler, 2011).

\section{Understanding student satisfaction}

Student satisfaction has become a central objective of the university and has been used to develop a culture of continuous quality improvement by stimulating student choice and institutional competition (DBIS, 2011; Williams, 2013). Several studies have developed measurement tools to reveal the drivers for student satisfaction at undergraduate level (Douglas, McClelland \& Davies, 2008; Douglas et al., 2014). For example, Douglas, McClelland \& Davies (2008) introduced a conceptual model that used critical incident 
techniques to analyze student satisfaction. One strong belief is that the focus on student satisfaction could enable universities to adapt to student needs and develop systems to meet those needs more effectively (Letcher \& Neves, 2010). Growing institutional interest in satisfaction surveys also reflects an awareness that such surveys are influential in aggregate rankings (Gibbons, Neumayer \& Perkins, 2013). Moreover, the measurement of student satisfaction at $\mathrm{PhD}$ level education has been focused on institutional and departmental responsibilities for doctoral student progress and success (Barnes \& Randall, 2012; Ehrenberg et al, 2009), instead of looking into the nature of student satisfaction and how individual students understand that. This ignores the fact that university study is not always an easy or happy experience, as students may encounter experiences which are emotionally challenging, but essential for their intellectual development (Collini, 2012).

The complexity of student satisfaction is further evidenced in the lack of consensus about how satisfaction can be measured and assessed from an academic perspective (Giese \& Cote, 2000). One view is that satisfaction could be an outcome of a consumption activity or experience (Parker \& Mathews, 2001), and that it represents the sum of a student's academic, social, physical, and spiritual experiences (Elliott \& Shin, 2002). A common approach is the student survey which assesses students' satisfaction with different educational experiences and then aggregates these assessments into an overall satisfaction score (Douglas et al., 2014).

However, studies reveal that it is difficult to attach student satisfaction to any specific educational outcomes, because satisfaction can be a fulfillment response and a state of mind felt by a student who has experienced an outcome that meets their expectations (Kotler \& Clarke, 1987; Baron \& Corbin, 2012). For example, students may be satisfied with their academic programmes, but may be disappointed at tuition prices or with the academic support provided (Kotler \& Fox, 1995; Tuan, 2012). This implies that satisfaction can be a short-term attitude, resulting from the assessment of one's specific educational experience at one point in time, rather than their overall long-term experience (Summers, Waigandt \& Whittaker, 2005). This emphasis on the short-term suggests that satisfaction is essentially a subjective attitude, similar to the main argument of expectancy-value theory. However, feelings and emotions are rarely taken into account as variables in measurements of student satisfaction (Wirtz \& Bateson, 1999; Bolliger \& Halupa, 2012), despite the fact that satisfaction has been used to show how students believe that the use of the educational services can generate positive feelings (Sumaedi, Bakti \& Metasari, 2011). 


\section{Research methods}

Based on these ideas, this research uses expectancy-value theory as a framework to reveal the key factors that influence levels of satisfaction experienced by individual research students, and how student satisfaction is perceived as related with quality education. It explores whether student satisfaction can be influenced by student expectations prior to study and the perceived value of undertaking the $\mathrm{PhD}$, including the personal importance of education, costs of doing a $\mathrm{PhD}$, interest in the subject area and career goals.

The research uses data from case studies of two universities in the UK. One university enjoys an international status as a world leading institution, and the other has established a strong reputation for both teaching and research, according to Times Higher Education World University Rankings. Semi-structured interviews were conducted with $16 \mathrm{PhD}$ supervisors and $16 \mathrm{PhD}$ students, allowing flexible lines of inquiry and the possibility to explore perspectives in depth (Denscombe, 2010). Research ethics were carefully considered and ethical approval was granted before data collection. The interviewees were selected from three disciplinary areas, education, physics and engineering, to provide multidisciplinary views of quality education and student satisfaction. A consent form and an information sheet were given before each interview, outlining the objectives of the research, the criteria for selection of respondents and the rights of each respondent. All 32 interviews were audiorecorded and transcribed. Thematic analysis (Boyatzis, 1998) was used to analyze the interview data. NVivo software was used to facilitate the coding of the data (Welsh, 2002), in order to ensure that the data was analyzed in a rigorous and transparent manner (Cresswell, 2013).

\section{Research findings}

The majority of interviewees perceived the concepts of student satisfaction and quality education as different, but related. They described satisfaction as a subjective attitude which varied at different stages of a $\mathrm{PhD}$ study, while quality education was academic standard related, and had four dimensions: context, inputs, process and outcome. The context was the environment within which the activity of $\mathrm{PhD}$ education occurred. Inputs included the 
learning resources, including libraries, computer facilities, and laboratories. Students' learning processes involved interaction with peers, other students and supervisors, and included students' understandings of learning and experiences of support, their expectations, self-confidence and personal and professional development. Outcomes referred to what students achieved at the end of their $\mathrm{PhD}$ study, such as a thesis, publication and, most importantly, a job.

\section{Emotion-led student satisfaction}

Despite the awareness of the importance of fostering student satisfaction, a third of supervisor interviewees pointed out that students could get dissatisfied easily with a normal and high quality education. A supervisor in engineering explained that this arose because sometimes a quality education might not be "full of fun":

We strive for the highest quality experience for students and that doesn't always mean they enjoy it! We still have people who come and deliver presentations to students whose presentation style is very dry, but what they are saying is so important for students to know and understand. (Interviewee 22)

This argument suggests that student satisfaction is not necessarily decided by academic standards or the importance of the teaching content, but by how students feel about it. This confirms the view of expectancy value theory that satisfaction can be emotion-led, i.e. an attitude (Eccles \& Wigfield, 2002). Half the student interviewees shared the view that a quality experience could be highly challenging, and therefore might not lead to student satisfaction. For example, a student interviewee in education strongly argued for distinguishing satisfaction from quality, as he recognized that a quality experience could be uncomfortable:

One of the professors from the very first day of the MPhil said that "We're going to make you a little uncomfortable" and I knew I was in the right place because part of the learning process is learning how to live with a certain amount of (laugh) discomfort. ...If we're always comfortable we might not be learning a whole lot. (Interviewee 1)

A similar situation can also be experienced in supervision. A supervisor in engineering gave an example to illustrate that student satisfaction does not necessarily mean that the student actually learned something useful from a supervision session: 
For example, you can be very happy with the supervision session with me, I can be incredibly nice to you, but you probably may not learn anything at the end of it, so in that sense satisfaction can become meaningless and void of substance. (Interviewee 21) The implications of this example are that satisfaction reflects how students feel at a particular time, and should be treated as a short-term subjective attitude instead of an assessment of the overall educational experience (Summers, Waigandt \& Whittaker, 2005). Most interviewees related this subjectivity with mood changes. For example, a supervisor in education argued that the $\mathrm{PhD}$ was such a solitary activity that mood change could significantly affect students' opinions of their satisfaction.

$\mathrm{PhD}$ students suffer violent mood swings throughout their $\mathrm{PhD}$, so there's not a sense of overall satisfaction, but at any given point you could say, "Are you satisfied or not?" and the opinion might change. (Interviewee 25)

Six interviewees pointed out that the emotional side of satisfaction had rarely been measured in the practice of seeking students' feedback and in student surveys. This confirms the argument of Bolliger \& Halupa (2012) that feelings and emotions should be considered as variables in the measurement of student satisfaction.

\section{The dimensions of student satisfaction}

Most interviewees believed that student satisfaction and quality education could be at opposite ends of a spectrum depending on personal value propositions and individual goals. They recognised that the reasons and goals for individual students to undertake $\mathrm{PhD}$ study could significantly affect the level of their satisfaction. According to expectancy value theories, their identified reasons and goals can be classified as four kinds: personal importance of doing well in the study (attainment), effort of engaging in the $\mathrm{PhD}$ study (cost), interest in the study (intrinsic values), and future career plan (utility values).

One third of the interviewees believed that quality education could lead to satisfaction if students were interested in having a quality education, because their interest would motivate them to learn, which, as a result, would increase their level of satisfaction. For example, a PhD student in physics argued that student satisfaction was not influenced by the quality of education until students were really into their study. 
If the student is interested in high quality then he would be satisfied if he felt he had achieved work of high quality, but, if the student is a lazy person (laugh), he is satisfied if he gets a $\mathrm{PhD}$ while going out drinking every night and having a nice time. (Interviewee 14)

This quotation clearly shows that students' perception of the importance of having a quality education will affect both their engagement with learning, and whether their satisfaction is academic performance related. This also suggests that $\mathrm{PhD}$ students were capable of identifying different key factors that influenced satisfaction and were aware that a challenging and rewarding educational experience would lead to satisfaction. Similarly, a $\mathrm{PhD}$ supervisor in education emphasized that satisfaction was determined by how much students cared about learning.

Well high quality is about a positive process for the student, but it also has a good outcome, where student satisfaction I think depends on the student. If the student doesn't care about how much they learn then they can still be very satisfied without actually having learnt that much. (Interviewee 12)

What this supervisor implied was that student attitudes and effort spent in learning reflected how much they valued $\mathrm{PhD}$ study, i.e., their appreciation of the importance of $\mathrm{PhD}$ education and their interest in the study. This corresponds well with expectancy-value theory in that the value students attach to their study could affect their attitude towards learning and subsequently their level of satisfaction. Another implication is that if satisfaction is used a simplistic measure of quality, it does not necessarily lead to positive learning outcomes.

Nearly all the interviewees were aware that getting a job that students really wanted might often lead to high levels of satisfaction with their learning experience, regardless of the actual quality of provision. Obtaining a job is one of the student utility values of doing a $\mathrm{PhD}$, and the values could the form of a valuable qualification or a route to a particular form of employment (Kaye, Bickel \& Birtwistle, 2006). However, supervisor interviewees tended to emphasize the importance of developing student interest in their subject area. They observed that students' intrinsic interest in the study might lead to more satisfaction than the utility values, as committed students often expressed more excitement arising from the development of original findings than those less motivated. A supervisor interviewee articulated this view as that follows:

I think satisfaction depends on why people are doing the $\mathrm{PhD}$. If they're doing the $\mathrm{PhD}$ for instrumental reasons because it's going to get a better job for them, and if 
their expectations are not met then they're going to be dissatisfied. But if they are doing the $\mathrm{PhD}$ for intrinsic reasons, then I suspect the satisfaction is part of that. (Interviewee 17)

This perception suggests that student satisfaction could easily become part of a $\mathrm{PhD}$ if related with students' intrinsic interest in the study, rather than their utility values of doing a PhD. According to Ryan and Deci (2000), this is because the intrinsic interest will make the learning process enjoyable, will lead to increased engagement with learning, and, as a result, will encourage a higher level of satisfaction.

\section{Expectations and student satisfaction}

Interviewees pointed out that a student's expectations of a $\mathrm{PhD}$ could affect their perceptions of their actual study experience, which, as a result, influenced the level of their satisfaction. This supports the conclusions of expectancy value theory in that student satisfaction will depend on what students expect before undertaking their study. The expectations revealed in this study include not only students' personal plans of what to get out of their $\mathrm{PhD}$, but also their supervisors' expectations for what students should be able to achieve during and by the end of the study. This suggests that satisfaction becomes a student's fulfillment response when an outcome meets their expectations (Kotler and Clarke, 1987). Here is one example of how students become satisfied when they feel confident of meeting their supervisor's expectations:

Students will feel satisfied if they're clear of what the expectations are of them and they feel that they're being put in an environment where they have some hope of achieving those expectations. (Interviewee 28)

However, sometimes there were different objectives that impacted upon students' understandings of expectation and their academic experience. For example, a student from education described how these different objectives could affect student satisfaction:

Student satisfaction depends on how they view what are the objectives of their academic experience. ... Sometimes there are issues in that. For example, we're based in education, many people have an interest in international education, but some events are based around British education, so there are different perceptions of what is important to the student. (Interviewee 7) 
This example suggests that it is important for students to be informed of specific expectations held by the school/department or supervisors, in order to avoid confusion and to improve student satisfaction. Students' expectations of their individual educational experiences may vary, so supervisors need to be sensitive to such variations as they will have an effect on satisfaction. For example, an international $\mathrm{PhD}$ student in engineering equated satisfaction with why he had pursued his PhD study and the fact that he had worked hard for that:

I was clear what I wanted the $\mathrm{PhD}$ for. I was clear in my country, we didn't have that specialization. I needed it, and it wasn't the case for some of my classmates who were just coming out of undergraduate. They just had a grant, you know, they had to do something after their undergraduate and they like the teachers who are fun, who are easy.... (Interviewee 8)

This argument further confirms the main thrust of expectancy-value theory that students' expectations of education can affect their attitudes and understandings of learning and, subsequently, their levels of satisfaction.

\section{The "cons" of an over-emphasis on student satisfaction}

Although most student and supervisor interviewees described student satisfaction as important, they had concerns that an over-emphasis on student satisfaction could pose a threat to quality. One view was that any such over-emphasis would encourage academic staff and universities to make things easier, so that students would feel happier, but that this would contradict the ultimate purpose of $\mathrm{PhD}$ education in that students needed to work hard and to contribute novel knowledge to their field. A supervisor explained that:

Students can be very satisfied if they've done something very worthwhile, so educationally you want really to challenge students as much as possible..., but there's a little bit of tension between that and student satisfaction, because students will be more satisfied the better they do, therefore they want it to be easier not harder. (Interviewee 21)

Supervisors from education argued strongly against the use of student satisfaction to measure quality, as satisfaction could hurt quality, if the demand for satisfaction meant that students became detached from their commitment to the quality of the $\mathrm{PhD}$. Interviewees related an over-emphasis on student satisfaction with the idea of students as consumers. Their concern was that supervisors would feel uncomfortable in challenging their students intellectually, notwithstanding that intellectual challenges were an essential element of $\mathrm{PhD}$ study. 
If it's taken into account in this very market driven idea of ... the student is the consumer and has to be happy, it could affect the relationship the supervisor will have with them because the supervisor soon will learn that and doesn't want the student saying they don't like him or her. (Interviewee 8)

This concern supports the argument of Molesworth, Nixon \& Scullion (2009) that too much focus on how to satisfy students does not necessarily benefit student learning, but encourages a culture of students as lazy learners.

\section{An analysis of quality}

As well as investigating the perceived relationship between student satisfaction and quality, this research explored interviewees' interpretations of quality education. Nearly all the interviewees stressed the importance of quality education and described it in terms of four dimensions: context, inputs, process and outcome. However, many supervisor interviewees pointed out that the word "quality" had been mainly used for management purposes, which made them treat quality like a box ticking exercise. For example, a supervisor in physics preferred the words 'student growth' (meaning personal development) to 'quality'.

The word 'quality' has become hijacked by these external measures, and we sort of go “OK, yes, we have to do that to meet the 'quality' indicators". ... But I never think about quality when I'm working with my own students.... I think about things like growth .... (Interviewee 18)

This argument suggests that the widespread approach of evaluating quality and the oversimplified association between quality and satisfaction have made academic staff doubt the purpose of advocating quality in education. However, the word "quality" resonated with interviewees' experiences of their own good work and with the work of others. They associated quality education with student expectations, most notably in the experience of support and in meeting their objectives for intellectual development.

Another factor to be considered regarding quality education was the "brand" of the institution. Most interviewees from the world-renowned university were satisfied with the quality of their $\mathrm{PhD}$ education. They equated quality with their university brand, because a top university could provide better learning resources and more famous professors than other, less prestigious, universities. In this way, satisfaction reflected the strength of the university brand and assumed quality rather than actual experiences. 
Interviewees pointed out that the measurement of quality has focused on inputs and outcomes, while the student learning process had rarely been considered. This corresponds with the argument of Joseph, Yakhou \& Stone (2005) that research on quality has relied excessively on the input from academics while excluding the input from the students themselves.

Nearly half the interviewees believed that, although people normally assessed quality by outcomes, the process was equally important as it relates to student engagement and levels of satisfaction, and that sometimes outcomes could be unpredictable. One example was that a student interviewee's thesis ended up being better than he had expected.

I think me and my supervisor are both quite surprised by how my thesis has ended up (laugh), which is quite nice actually. At the start of the field work I didn't know what these teachers are going to do, so while expectations are important there needs to be this flexibility for the unknown. (Interviewee 7)

The unexpected good results of this thesis suggest that, although the initial expectation is important, it can be moderated by how individuals envisage their outcomes. There might be other things that are unknown, because $\mathrm{PhD}$ research by its very nature is unpredictable. He felt that it was better to focus on the process, and to have expectations, but also to remain flexible and open-minded.

\section{Discussion and conclusion}

This research has demonstrated clearly that the concepts of student satisfaction and quality education are perceived as different, but connected, by $\mathrm{PhD}$ students and supervisors, and that an overemphasis on student satisfaction is perceived to pose a threat to the quality of education. These findings differ from existing research (Marzo-Navarro, Pedraja-Iglesias \& Rivera-Torres, 2005; Kahu, 2013) which argues that student satisfaction leads to quality education. This paper reveals that the complexity of quality education for $\mathrm{PhD}$ students lies in the belief that measurement should take into account not only the learning outcomes, but also the educational context, resources and process. It is worth noting that this paper does not intend to argue that the perceived relationship between quality education and $\mathrm{PhD}$ student satisfaction applies to all higher education contexts. This study aims to provide theoretical insights and a snapshot of how $\mathrm{PhD}$ students and $\mathrm{PhD}$ supervisors understand the nature of 
student satisfaction and how that is related to the quality of $\mathrm{PhD}$ education in their real experiences.

As previously discussed, quality has been used as a management concept, and there are strong calls for using the measurement of student satisfaction to demonstrate the quality of education. However, student satisfaction is a short-term, subjective attitude, and it does not assess students' overall educational experiences, but, rather, conflicts with the intellectual, challenging nature of $\mathrm{PhD}$ education. This is because the overemphasis on student satisfaction encourages the culture of students as customers and may reduce the opportunities for supervisors and the university to create intellectual challenges for $\mathrm{PhD}$ students. Thus, an over-emphasis on student satisfaction, especially when accompanied with forms of measurement and evaluation, may change the nature of the research student: supervisor relationship towards a more formal, contractual model (Gatfield, 2005: Lee, 2007).

Feelings and emotions were identified as key factors influencing the level of $\mathrm{PhD}$ student satisfaction, but they have not been used as variables in the current measurement of student satisfaction. Such measurements are complex to undertake and may often require the kind of longitudinal study that does not sit easily in university or political decision-making procedures. This raises questions regarding the effectiveness of measuring $\mathrm{PhD}$ student satisfaction to improve student learning. If student satisfaction continues to be used as an important indicator of the quality of education, it is necessary to weight different components of student satisfaction and measure them accordingly in order to improve the quality of education. Universities also need to understand that there are other factors that cannot be controlled that may influence the level of student satisfaction. Brands create expectations which influence satisfaction. For example, $\mathrm{PhD}$ student interviewees from the world-leading university were more satisfied with the quality of their $\mathrm{PhD}$ education than those from less prestigious university.

The perception of student satisfaction as a subjective attitude is in line with expectancyvalue theory in that students' expectations for their $\mathrm{PhD}$ education and the value they attach to it could affect their attitudes towards learning and subsequently their level of satisfaction. This suggests that one effective way to achieve quality education and student satisfaction is to encourage and increase students' interest and engagement in their learning process, because students' intrinsic values concerning a $\mathrm{PhD}$ education are more likely to lead to high levels of satisfaction and strong interest in learning than their utility values. This could be achieved 
through enhanced induction offered by the School/Department to specify explicit disciplinary academic standards and potential intellectual challenges, so that students understand their role in learning and the difference between quality education and student satisfaction. Meanwhile, universities need to reconsider the purpose of the measurement of quality education and student satisfaction, and turn it into a means to motivate students to learn. This involves refraining from the use of measurements of student satisfaction for the management of academics' performativity, and emphasising the evaluation of student progress during their study. Universities also need to encourage and promote academic practices that increase students' intrinsic interest in learning, and avoid a detrimental tendency whereby students will be treated like customers. In this study, both supervisors and research students were agreed that it was expert disciplinary knowledge, a contribution to new knowledge and research training that matter most in PhD level study.

\section{References}

Barnes, B. J. \& Randall, J. (2012). Doctoral student satisfaction: An examination of disciplinary, enrollment, and institutional differences. Research in Higher Education, 53(1): 47-75.

Baron, P. \& Corbin, L. (2012). Student engagement: rhetoric and reality. Higher Education Research \& Development, 31(6): 759-772.

Bolliger, D. U. \& Halupa, C. (2012). Student perceptions of satisfaction and anxiety in an online doctoral program. Distance Education, 33(1): 81-98.

Boyatzis, R. E. (1998). Transforming Qualitative Information: Thematic

Analysis and Code Development. London: Sage.

Bruggen, E.C., Fouber, B. \& Gremler, D. D. (2011). Extreme makeover: Short and long-term effects of a remodeled landscape. Journal of Marketing, 75 (5): 71-87.

Carbone, A. (2014). A peer-assisted teaching scheme to improve units with critically low student satisfaction: opportunities and challenges. Higher Education Research \& Development, 33(3): 425-439.

Cheng, M. (2011). The perceived impact of quality audit on the work of academics. Higher Education Research and Development, 30 (2): 179-191.

Coates, H. (2014). Students' early departure intentions and the mitigating role of support. 
Australian Universities Review, 56(2): 20-29.

Collini, S (2012). What are Universities For? London: The Penguin Group.

Cresswell, J. W. (2013). Qualitative Inquiry and Research Design: Choosing among Five Approaches $\left(3^{\text {rd }}\right.$ ed). London: Sage.

Denscombe, M. (2010). The good research guide: For small-scale research project ( $3^{\text {rd }}$ ed). Maidenhead: Open University Press.

Department for Business Innovation and Skills. (2011). Higher Education: Student at the Heart of the System. Retrieved December 20, 2014, from https://www.gov.uk/government/uploads/system/uploads/attachment_data/file/31384/ 11-944-higher-education-students-at-heart-of-system.pdf.

Douglas, J., McClelland, R., \& Davies, J. (2008). The development of a conceptual model of student satisfaction with their experience in higher education. Quality Assurance in Education, 16(1): 19-35.

Douglas, A. A., Douglas, A., McClelland, R. J., \& Davies, J. (2014). Understanding student satisfaction and dissatisfaction: An interpretive study in the UK higher education context. Studies in Higher Education, 39(1): 1-21.

Eccles, J. S., Adler, F. T., Futterman, R., Gof, B. S., Kaczala, M. C., Meece, J. \& Midgley, C. (1983). Expectancies, values and academic behaviors. In Spence, T. J. (Eds) Achievement and achievement motives (75-146). San Francisco: W. H. Freeman.

Eccles, J. S. (1987). Gender roles and women's achievement-related decisions. Psychology of Women Quarterly. 11(2):135-72.

Eccles, J. S., \& Wigfield, A. (2002). Motivational beliefs, values, and goals. Annual Review of Psychology. 53: 109-132.

Elliot, K., \& Shin, D. (2002). Student Satisfaction: An alternative approach to assessing this important concept. Journal of Higher Education Policy and Management, 24 (2): 197-209.

Ehrenberg, R. G., Zuckerman, H., Groen, J. A., Brucker, S. M. (2009). Educating Scholars: Doctoral Education in the Humanities. Princeton: Princeton University Press.

Gatfield, E., (2005). An investigation into PhD supervisory management styles: Development of a dynamic conceptual model and its management implications, Journal of Higher Education Policy and Management, 27, 3, pp311-25

Gibbons, S., Neumayer, E., and Perkins, R. (2013). Student satisfaction, league tables and university applications, Swindon: ESRC

Giese, J., \& Cote, J. (2000). Defining customer satisfaction. Academy of Marketing Science Review. $\quad$ Retrieved $20 \quad$ September, 2014, from http://www.amsreview.org/articles/giese01-2000.pdf.

Gruber, T., Fuß, S. Voss, R. \& Zikuda, M.G. (2010). Examining student satisfaction with 
higher education services: Using a new measurement tool. International Journal of Public Sector Management, 23 (2): 105-123.

Harvey, L. (2006). Impact of quality assurance: Overview of a discussion between representatives of external quality assurance agencies. Quality in Higher Education, 12(3): 287-90.

Higher Education Academy. (2014). Postgraduate Research Experience Survey (PRES) - UK reports. $\quad$ Retrieved March 11, 2014, http://www.heacademy.ac.uk/resources/detail/postgraduate/pres-reports.

Higher Education Funding Council for England. (2011). Review of the 2008 National Student Survey (NSS) process. Retrieved January 2, 2014, from http://www.hefce.ac.uk/data/year/2008/reviewofthe2008nationalstudentsurveynssproc ess/.

Ismail, A., Abdullah, M. M. B, \& Francis, S. K. (2009). Exploring the Relationships among Service Quality Features: Perceived Value and Customer Satisfaction. Journal of Industrial Engineering and Management, 2(1): 230-250.

Joseph, M., Yakhou, M. \& Stone, G. (2005). An educational institution's quest for service quality: customers' perspective, Quality Assurance in Education, 13(1): 66-82.

Kahu, E. R. (2013). Framing student engagement in higher education. Studies in Higher Education, 38(5): 758-773.

Kaye, T., Bickel, R. \& Birtwistle, T. (2006). Criticizing the image of the student as consumer: Examining legal trends and administrative responses in the US and the UK. Education and the Law, 18(2-3): 85-129.

Kotler, P., \& Clarke, R. N. (1987). Marketing for health care organizations. New York: Prentice-Hall.

Kotler, P., \& Fox, K. A. (Eds.). (1995). Strategic Marketing for Educational Institutions. New York: Prentice-Hall.

Lee, A. (2008). How are doctoral students supervised? Concepts of doctoral research supervision. Studies in Higher Education, 33(3): 267-81.

Letcher, D.W., \& Neves J.S. (2010). Determinant of undergraduate business student satisfaction. Research in Higher Education Journal, 6(1): 1-26.

Marzo-Navarro, M., Pedraja-Iglesias, M., \& Rivera-Torres, M. P. (2005). Measuring customer satisfaction in summer courses. Quality Assurance in Education, 13 (1): 5365.

Molesworth, M., Nixon, E. \& Scullion, R. (2009). Having, being and higher education: the marketization of the university and the transformation of the student into consumer. Teaching in Higher Education, 14(3): 277-287. 
Nair, C.S., Murdocj, M., \& Mertova, P. (2011). Benchmarking the student experience: the offshore campus experience. The TQM Journal 23(6): 585-97.

Nixon, M., \& Scullion, R. (Eds.). (2010). The Marketisation of Higher Education and the Student as Consumer. London: Routledge.

Oldfield, B., \& Baron, S. (2000). Student perceptions of service quality in a UK university business and management faculty. Quality Assurance in Education, 8(2): 85-95.

Palacio, A. B., Meneses, G. D., \& Perez, P. J. P. (2002). The configuration of the university image and its relationship with the satisfaction of students. Journal of Educational Administration, 40(5): 486-505.

Parker, C., \& Mathews, B. P. (2001). Customer satisfaction: Contrasting academic and consumers' interpretations. Marketing Intelligence \& Planning, 19 (1): 38-46.

Rowley, J. (1996). Measuring quality in higher education. Quality in Higher Education, 2(3): 237-255.

Ryan, R. M. \& Deci, E. L. (2000). Intrinsic and extrinsic motivations: classic definitions and new directions. Contemporary Educational Psychology, 25(1): 54-67.

Shah, M. (2012). Ten Years of External Quality Audit in Australia: Have Audits Improved Quality Assurance in Universities? Assessment and Evaluation in Higher Education, 37 (6): 761-772.

Singh, G. (2002). Educational consumers or educational partners: a critical theory analysis. Critical Perspectives on Accounting, 13(5): 681-700.

Sum, V., McCaskey, S.J. \& Kyeyune, C. (2010). A survey of satisfaction levels of graduate students enrolled in a nationally ranked top-10 program at a mid-western university, Research in Higher Education Journal, 7 (2); 1-17

Sumaedi, S., Bakti, I. G. M. Y., \& Metasari, N. (2011). The Effect of Students' Perceived Service Quality and Perceived Price on Student Satisfaction. Management Science and Engineering, 5(1): 88-97.

Summers, J., Waigandt, A., \& Whittaker, T. (2005). A Comparison of Student Achievement and Satisfaction in an Online Versus a Traditional Face-to-Face Statistics Class. Innovative Higher Education, 29(3): 233-250.

Tuan, N. M. (2012). Effects of service quality and price fairness on student satisfaction. International Journal of Business and Social Science, 3(19): 132-150.

Vauterin, J. J., Linnanen, L., \& Marttila, E. (2011). Issues of delivering quality customer service in a higher education environment. International Journal of Quality and Service Sciences, 3(2): 181-198.

Welsh, E. (2002). Dealing with data: Using NVivo in the qualitative analysis process. Forum Qualitative Social Research, 3(2). Retrieved Nov, 7, 2014, from http://www.qualitative-research.net/index.php/fqs/article/view/865/1881. 
Williams, J. (2013). Consuming Higher Education: Why Learning Can't be Bought. London: Bloomsbury.

Wirtz, J., \& Bateson, J E. G. (1999). Consumer Satisfaction with Services: Integrating the Environmental Perspective in Services Marketing into the Traditional Disconfirmation Paradign. Journal of Business Research, 44 (1): 55-66.

Total words: 6,902 